\title{
PROCESS REDESIGN UNTUK PEMILIHAN KETUA UMUM ORGANISASI KEMAHASISWAAN MENGGUNAKAN METODE BUSINESS PROCESS MANAGEMENT
}

\author{
R Budi Raharjo ${ }^{1}$, Nur Fitriani $F^{2}$, Shafira Mutiara $\mathbf{N}^{3}$ \\ Program Studi Sistem Informasi, Fakultas Teknologi Industri \\ Institut Teknologi Nasional \\ Jl. PH.H. Mustapa No. 23, Bandung \\ budiraharjo@itenas.ac.id ${ }^{1}$, nurfitrianti@itenas.ac.id $^{2}$, shafirabarbie@gmail.com $^{3}$
}

\begin{abstract}
Abstrak
Pada umumnya periode kepemimpinan di organisasi kemahasiswaan berlangsung selama satu tahun. Pada setiap tahunnya selalu diadakan pemilihan ketua umum yang dipilih secara langsung oleh seluruh anggota dari organisasi tersebut. Namun selama ini proses pemilihan calon ketua umum pada organisasi kemahasiswaan di Itenas dilakukan dengan cara manual tanpa menggunakan teknologi. Sementara saat ini perkembangan teknologi informasi sudah berkembang sangat pesat, pemungutan suara dan perhitungan suara dapat dilakukan menggunakan evoting. Namun untuk melaksanakan pemilihan yang transparan dan adil pada proses e-voting membutuhkan sebuah sistem yang bersifat desentralisasi. Teknologi blockchain dipercaya dapat mendukung proses transparansi ini karena setiap hasil vote akan di sinkronisasi pada komputer yang lain. Proses perubahan yang dilakukan dari pemilihan manual tanpa menggunakan teknologi sampai dengan menggunakan blockchain pada sistem e-voting dipetakan menggunakan metode BPM (Business Process Management). Oleh karena itu, penelitian ini memperlihatkan rancangan sistem e-voting dengan menggunakan teknologi blockchain dan menerapkannya pada sistem penghitungan suara sehingga dapat menjadi solusi untuk melaksanakan pemilihan yang transparan dan adil.
\end{abstract}

Kata Kunci: BPM, e-voting, blockchain \& transparansi

\section{Abstract \\ Commonly, the period of leadership in a student organizations lasts for one year. Therefore, there will be an annual head election which will be followed by}

all the members of the organization. But, all this time, the new head election process in ITENAS still being held manually without using technology. Meanwhile, nowadays technology has developed very rapidly, voting and vote counting can be done using e-voting. However, to hold a fair and transparent election need a decentralized system in the process of E-voting. Blockchain technology supports this transparency process because every vote will be synchronized on another computer. The process of change made from manual selection without using any technology to using the blockchain on the e-voting system is mapped using the BPM (Business Process Management) method. Therefore, this study shows the design of an e-voting system using blockchain technology and applies it to the vote counting system so that it can be a solution to carry out transparent and fair elections.

Keywords: BPM, e-voting, blockchain \& transparency

\section{Pendahuluan}

Selama ini proses pergantian ketua umum untuk organisasi kemahasiswaan di Itenas dilakukan dengan cara melaksanakan pemilihan langsung yang diikuti oleh seluruh mahasiswa yang aktif didalam organisasi tersebut. Pemilihan digunakan untuk menghimpun aspirasi dari seluruh elemen masyarakat, dan kemudian menemukan jalan keluar yang dianggap paling baik untuk menyelesaikan permasalahan (Maryasa, 2018). Namun pada proses pemilihan yang berlangsung secara manual tanpa menggunakan teknologi memiliki beberapa kelemahan dan juga resiko terjadinya kecurangan lebih besar dibandingkan dengan menggunakan teknologi.

R Budi Raharjo, Nur Fitriani F, Shafira Mutiara N 
Karena pada pelaksanaannya pemilihan ketua umum di organisasi kemahasiswaan memiliki proses yang hampir sama dengan pemilihan umum yang biasa dilakukan pada saat pemilihan presiden dan lain-lain. Dan berikut merupakan denah dari kegiatan pemilihan umum yang umumnya dilakukan terlihat seperti pada Gambar 1.

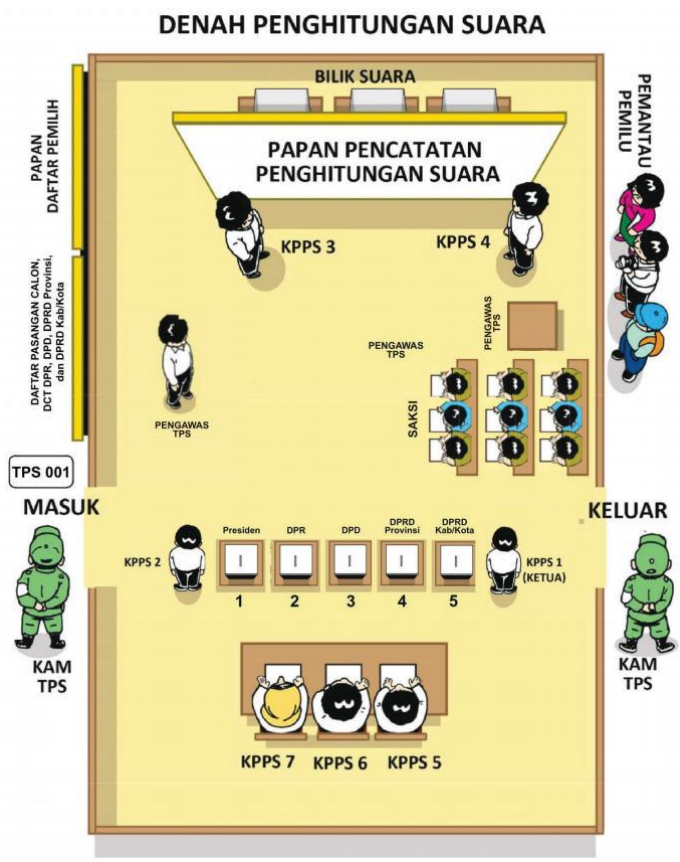

Gambar 1. Denah Kegiatan Pemilihan Umum (Sumber : https://ppsdesa.purwawinangun.id/tugaskelompok-penyelenggara-pemungutan-suara-kpps/)

Proses pemilihan umum calon ketua umum organisasi dilakukan dengan cara yang hampir sama seperti pada Gambar 1, dengan menggunakan bilik suara dan peralatan kantor lainnya. Kemudian, mahasiswa yang merupakan anggota dari organisasi tersebut datang dengan membawa KTM (Kartu Tanda Mahasiswa) sebagai syarat masih berstatus mahasiswa di universitas tersebut. Kemudian mahasiswa tersebut menerima surat suara yang berisikan foto dari calon ketua lalu mahasiswa tersebut memilih dengan cara mencoblos salah satu foto calon ketua. Setelah melakukan pemilihan sebagai tanda telah berkontribusi didalam kegiatan pemilihan umum pemilih mencelupkan jari ke tinta, memasukan surat suara kedalam kotak suara dan juga melakukan absen. Setelah seluruh anggota selesai melakukan pemilihan, perhitungan surat suara dilakukan oleh panitia yang bertugas dan disaksikan oleh beberapa anggota lain sebagai saksi.
Akan tetapi, proses pemilihan ketua umum yang dilakukan oleh beberapa organisasi kemahasiswaan di Itenas dapat berlangsung selama berhari-hari. Pada saat itu, kotak suara dapat ditinggalkan tanpa adanya pengawasan. Yang dikhawatirkan dapat terjadinya kecurangan yang mungkin saja dilakukan oleh oknum yang tidak bertanggung jawab.

Karena itulah dibutuhkan sebuah solusi untuk memberikan keamanan pada data hasil pemilihan dan juga transparansi pada saat proses perhitungan suara. Beruntung saat ini teknologi informasi sudah memadai untuk mendukung jalannya proses pemilihan hingga perhitungan suara. Teknologi yang dimaksud yaitu, penggunaan sistem $e$-voting berbasis blockchain.

E-voting sendiri merupakan solusi alternatif yang diusulkan, karena pada penerapannya $e$-voting masih memiliki kekurangan terutama pada bagian keamanan data dan transparansi. E-voting sendiri merupakan metode pemilihan suara dengan menggunakan perangkat elektronik ((BPPT) Badan Pengkajian dan Penerapan Teknologi, (2017)). Penerapan e-voting pada pemilihan umum dirasa dapat memangkas proses yang ada pada pemilihan umum manual tanpa menggunakan teknologi dan juga dapat memangkas biaya untuk melakukan pemilihan umum (Yusriannur, 2014).

Kemudian untuk memberikan keamanan pada data pemilihan dan juga mendukung transparansi ketika penghitungan suara, teknologi blockchain dapat menjadi solusinya. Teknologi blockchain merupakan solusi dari penerapan sistem e-voting yang jujur dan transparan. Karena blockchain yang menganut sistem desentralisasi dan seluruh database dimiliki salinannya oleh banyak pengguna. Dengan mengadopsi blockchain dalam pencatatan database pada sistem evoting dapat mengurangi salah satu sumber kecurangan yaitu manipulasi database. Karena siapapun yang bisa masuk dan menambahkan data, ketika ada yang menambahkan database disetiap komputer yang membuka akses tersebut bisa mengetahui ada penambahan data (Hanifatunnisa \& Rahardjo, 2017). Maka ketika ada update data, data sudah tidak bisa diganggu gugat oleh siapapun. Dan proses penghitungan suara pun bisa terlaksana dengan adil, jujur dan transparan tanpa adanya manipulasi data dan atau bentuk kecurangan lainnya.

Berdasarkan latar belakang yang telah dipaparkan, rancangan dari sistem ini akan dipetakan menggunakan 
BPR (Business Process Redesign) dengan rumusan masalah sebagai berikut:

1) Bagaimana menganalisa proses pemilihan umum di organisasi kemahasiswaan khususnya di itenas.

2) Bagaimana memetakan proses pemilihan ketua umum di organisasi tersebut dan memperbaiki proses tersebut.

Dari rumusan masalah yang ada dapat ditentukan tujuan dari penelitian ini yaitu membuat analisa, pemetaan proses pemilihan ketua umum organisasi kemahasiswaan dan melakukan perbaikan pada proses tersebut menggunakan metode BPR

\section{KAJIAN LITERATUR}

\section{II.1 Business Process Management}

Business Process Management (BPM) merupakan metodologi pengembangan perangkat lunak yang digunakan dalam pembuatan aplikasi e-voting ini. BPM adalah disiplin ilmu dalam manajemen operasi dimana orang menggunakan berbagai metode untuk menemukan, memodelkan, menganalisis, mengukur, meningkatkan, mengoptimalkan, dan mengotomatiskan proses bisnis (Jeston \& Neils, 2014). Proses BPM merupakan cara terorganisir untuk mengoptimalkan proses perubahan dalam meningkatkan proses bisnis yang bersifat lintas fungsi dan memanfaatkan teknologi secara maksimal (Menaesolution, 2019). Berikut adalah gambaran dari proses-proses yang terdapat pada BPM terlihat seperti pada Gambar 2.

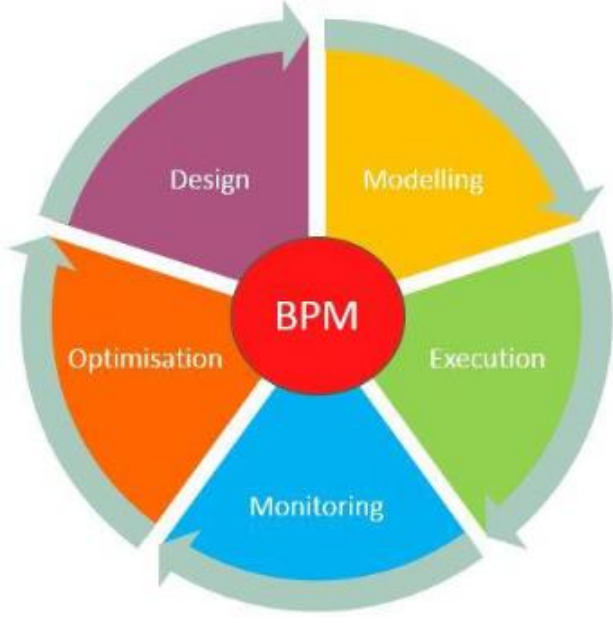

Gambar 2. Lifecycle BPM

(Sumber: https://creativecommons.org/licenses/by-sa/3.0 \&GFDL (https://www.gnu.org/copyleft/fdl.html)

1) Desain adalah langkah pertama dalam lifecycle BPM. Pada proses ini adalah melakukan dokumentasi bersama dalam bentuk grafik yang dibuatkan alur lengkapnya untuk menunjukkan proses secara detail.

2) Pemodelan diagram proses dianalisis. Aliran dan langkah ditinjau, inefisiensi diidentifikasi dan aliran alternatif dimodelkan. Dengan menggunakan notasi tertentu. Aliran dan langkah ditinjau, inefisiensi diidentifikasi dan aliran alternatif dimodelkan.

3) Eksekusi, pada langkah ini eksekusi dilakukan untuk melakukan perubahan dan peningkatan diimplementasikan.

4) Memantau, setelah proses perlu dipantau kinerja pelaksanaannya.

5) Optimalisasi adalah langkah terakhir, sebagai bagian dari proses optimasi yang berkesinambungan (Brocke, 2010).

\section{II.2 Milestone}

Milestone merupakan pola atau serangkaian tugas dalam proses organisasi, yang membentuk aspek dari urutan aktivitas yang terhubung dan kemudian membentuk menjadi sebuah alur kerja. Milestone dapat dianggap sebagai bagian dari keseluruhan dalam jaringan tugas proses. Karena setiap langkah dalam pola yang terdapat di milestone berkontribusi pada 
keseluruhan alur kerja yang dapat dieksekusi (Aaiim, 2019).

\section{II.3 Analyze Link}

Analyze link adalah daftar tugas atau pola yang sudah tersusun dan membentuk sebuah proses end-toenduntuk menentukan alur kerja keseluruhan. Agar proses bisnis dapat dioptimalkan alur kerjanya secara sistematis (Aaiim, 2019).

\section{II.4 Proses Bisnis}

Proses bisnis merupakan inti dari seluruh aktivitas pada suatu perusahaan atau organisasi. Untuk mencapai tujuan perusahaan, proses bisnislah yang memberdayakan seluruh sumber daya yang ada pada perusahaan. Setiap bisni memiliki proses masingmasing yang unik, sesuai dengan karakteristik dari perusahaan dan bidang usahanya. Pada pelaksanaan proses bisnis ini akan ditemukan permasalahan yang ada dan diharapkan juga menemukan solusi untuk permasalahan yang ditemukan dan dapat mengimplementasikan solusinya (IPQI, 2018).

\section{Metode Penelitian}

Berikut adalah metode yang digunakan dalam penelitian ini, berikut juga dengan pemetaannya seperti yang terlihat pada Gambar 3 .

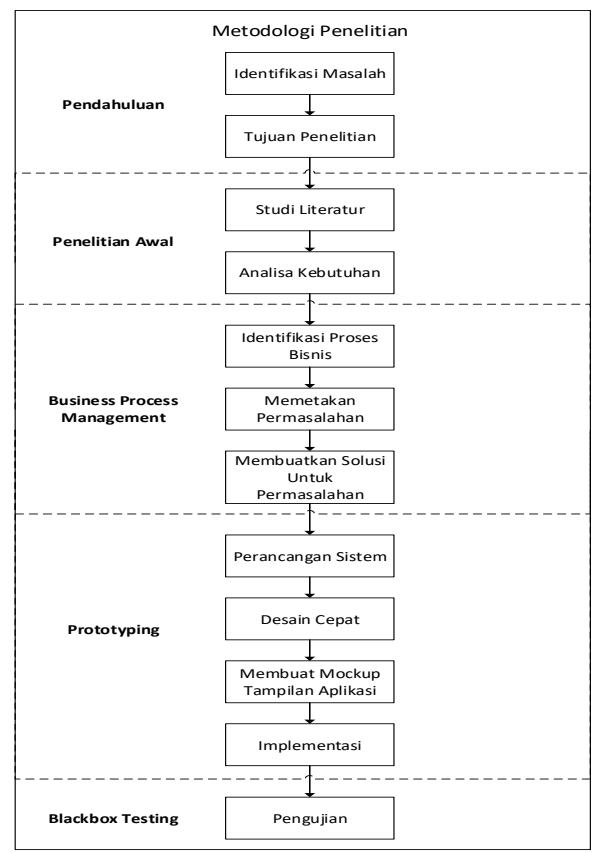

Gambar 3. Metodologi Penelitian

\section{1) Pendahuluan}

Diawali dengan melakukan identifikasi permasalahan pada proses pemilihan umum yang manual tanpa menggunakan teknologi kemudian setelah masalah ditemukan dibuatlah rumusan masalah dan tujuan dari penelitiannya

\section{2) Penelitian Awal}

Mencari dan mempelajari berbagai macam literatur ataupun sumber informasi baik buku, artikel, jurnal, majalah maupun dari situs internet yang berhubungan dengan sistem yang dibangun. Setelah melakukan studi literatur, selanjutnya melakukan analisa kebutuhan untuk melanjutkan penelitian. Dari mulai kebutuhan perangkat keras, perangkat lunak dan juga data dan informasi dari studi kasus yang terlibat.

\section{3) Pemetaan Proses}

Pemetaan proses dilakukan untuk membantu menganalisa, menemukan masalah dan membuat solusi dari proses-proses yang terjadi selama pemilihan ketua umum pada organisasi kemahasiswaan di Itenas, dalam tahap ini metode yang digunakan yaitu BPM (Business Process Management).

Kemudian untuk tahap berikutnya, pembuatan prototype, implementasi dan pengujian dilakukan pada penelitian selanjutnya. Karena pada penelitian ini, difokuskan pada redesigning proses dari manual tanpa menggunakan teknologi menjadi menggunakan sistem e-voting dengan pemanfaatan teknologi blockchain.

\section{HASIl AnAlisis}

\section{IV.1. Pembahasan}

Proses pemilihan umum yang dilakukan oleh organisasi kemahasiswaan di Itenas masih menggunakan sistem yang manual tanpa menggunakan teknologi apapun, dilakukan dengan menggunakan kertas dan bilik suara. Proses terlihat seperti pada Gambar 4. 


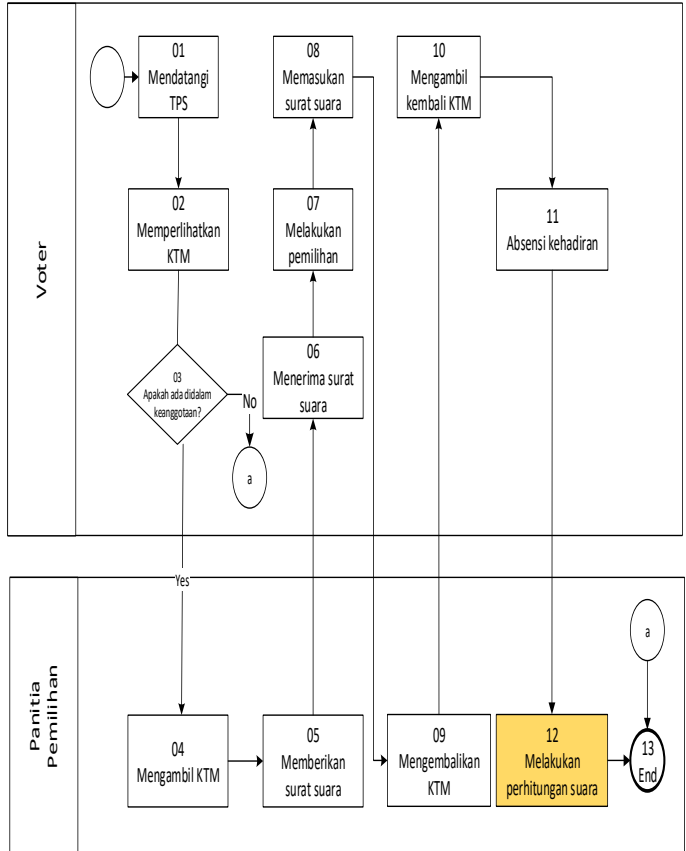

Gambar 4. Proses Pemilihan Umum Manual Tanpa Menggunakan Teknologi (Dibuat Menggunakan Notasi BPM)

Seperti pada Gambar 4 proses pemilihan dimulai dari proses bisnis no 1 yaitu, pemilih mendatangi TPS (Tempat Pemungutan Suara) lalu memperlihatkan KTM kepada panitia yang bertugas untuk memastikan bahwa calon pemilih ini merupakan anggota dari TheCabanas dan masih berstatus sebagai mahasiswa di Itenas. Jika calon pemilih tersebut benar merupakan anggota TheCabanas dan masih berstatus sebagai mahasiswa maka panitia akan memberikan surat suara yang akan digunakan oleh pemilih untuk mencoblos salah satu dari calon ketua yang tersedia. Setelah memilih, pemilih memasukan surat suara kedalam kotak suara lalu mengambil kembali KTM nya, mengisi daftar hadir dan menyelupkan jari ke tinta sebagai tanda telah melakukan pemilihan calon ketua.

Setelah proses pemilihan selesai, selanjutnya memasuki tahap penghitungan suara seperti yang tertera pada proses bisnis no. 12, yang juga dilakukan secara manual. Dengan disaksikan oleh anggota TheCabanas, panitia dan juga kedua calon ketua TheCabanas. Perhitungan dilakukan seperti pada TPS umumnya dengan membuka surat suara lalu menuliskan poin disetiap suara yang sudah dihitung sampai surat suara terakhir dan mendapatkan pemenangnya. Dan pada proses ini kemungkinan terjadinya kecurangan dapat terjadi.
Pada proses pemilihan manual tanpa menggunakan teknologi ini terdapat kekurangan yaitu proses yang kurang efisien dan juga kemungkinan terjadinya kecurangan pada saat perhitungan suara juga dapat terjadi apabila kurang adanya pengawasan. Setelah menganalisis proses pemilihan umum yang dilakukan oleh organisasi tersebut dengan cara yang manual dan juga ditemukan kekurangan pada proses tersebut, karena proses yang dilakukan secara manual memungkinkan dapat terjadinya kesalahan atau bahkan kecurangan.

Diusulkanlah untuk membangun sistem $e$-voting dengan menggunakan teknologi blockchain. Karena dengan dibuatnya sistem $e$-voting diharpakan dapat mengatasi permasalahan yang timbul dari pemilu yang diadakan secara manual seperti:

1) Mempercepat penghitungan suara

2) Hasil penghitungan suara lebih akurat

3) Menghemat bahan cetakan untuk kertas suara

Namun untuk melihat perbandingan proses $e$ voting biasa tanpa menggunakan teknologi blockchain dengan yang menggunakan blockchain, berikut adalah gambaran dari proses e-voting biasa seperti yang terlihat pada

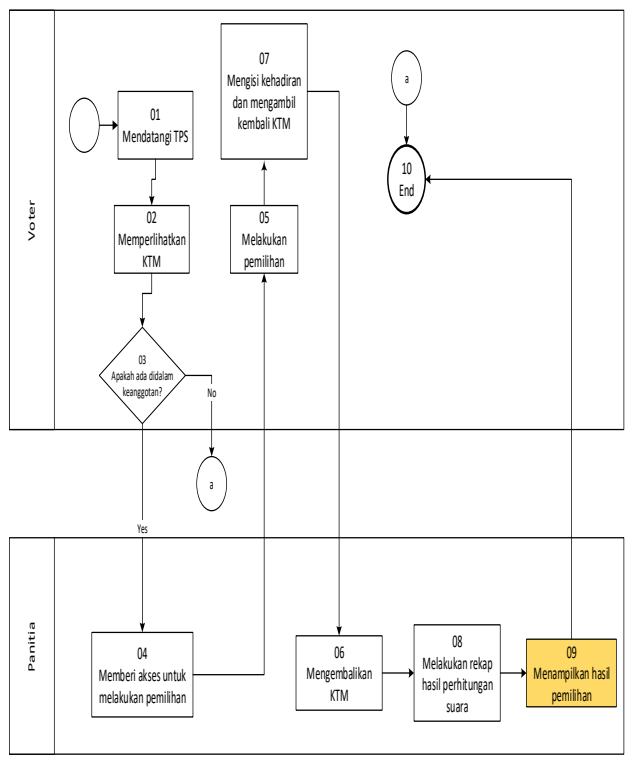

Gambar 5. Proses Menggunakan E-voting (Digambarkan Menggunakan Notasi BPMN)

Alur proses yang dilalui pemilihan menggunakan $e$-voting tidak berbeda jauh dengan pemilihan suara manual, karena pemilih tetap harus mendatangi TPS dan memperlihatkan KTM. Namun pada pemilihan 
dengan aplikasi $e$-voting proses pemilihan dilakukan menggunakan komputer begitupun perhitungan suaranya. Ketika peserta pemilih sudah terverifikasi sebagai anggota organisasi tersebut, peserta akan diberikan akses untuk melakukan pemilihan dikomputer yang sudah tersedia. Selanjutnya, peserta pemilih hanya tinggal memilih salah satu dari calon ketua selanjutnya. Ketika sudah melakukan pemilihan, peserta megambil kembali KTM dan mengisi daftar hadir. Data hasil pemilihan langsung dikalkulasi ketika peserta telah melakukan pemilihan. Kemudian data hasil pemilihan dapat langsung ditampilkan. Tetapi pada proses 08 dan 09 ketika admin sedang melakukan perhitungan dan akan menampilkan hasil pemilihan.

Dalam hal ini, aplikasi e-voting memberikan manfaat yang tidak didapatkan dari pemilihan manual. Namun aplikasi e-voting ini masih memiliki kerentanan yaitu:

1) Modifikasi data dalam database yang bisa saja dilakukan oleh admin.

2) Proses perhitungan suara masih kurang transparan

3) Proses yang dilakukan masih tidak efisien

Sehingga dibutuhkan solusi lainnya yang bersifat transparan dan mampu menghilangkan kecurangan pada saat perhitungan hasil pemilihan agar pemilihan berlangsung jujur dan adil bagi pemilih dan juga bagi organisasi yang melaksanakannya.

Untuk mengatasi permasalahan yang ada, dibangunlah aplikasi $e$-voting dengan menggunakan teknologi blockchain. Sistem blockchain dapat memberikan keuntungan diantaranya:

1) Menghemat pengeluaran karena hampir $100 \%$ paperless

2) Hasil penghitungan suara lebih akurat dan tidak dapat diganggu gugat oleh siapapun

3) Pembuatan dan penggunaan aplikasi tidak mengeluarkan biaya apapun

4) Perhitungan suara menjadi transaparan dan adil

Berikut adalah alur dari proses $e$-voting dengan menggunakan teknologi blockchain terlihat pada

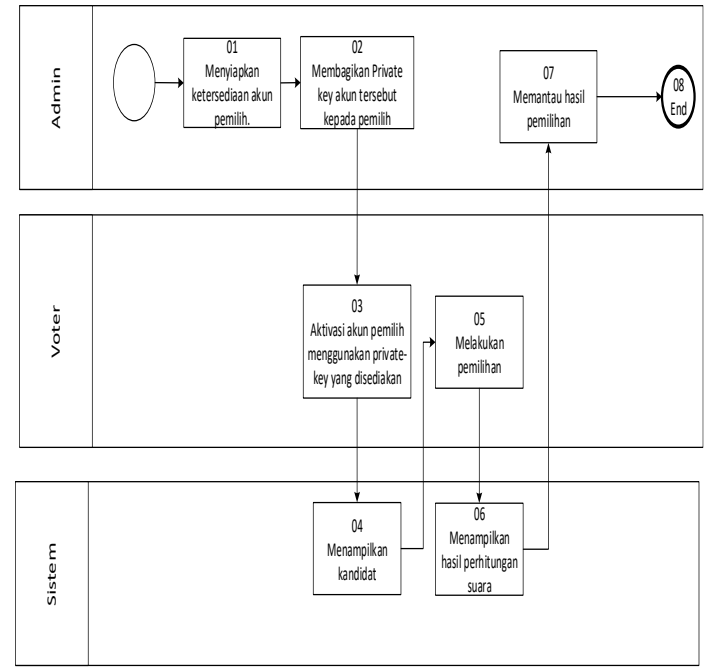

Gambar 6. Proses Aplikasi E-voting Berbasis Blockchain

(Dibuat Menggunakan Notasi BPMN)

Seperti yang terlihat pada Gambar 6 proses dimulai dari admin yang mengirimkan private-key dari akun blockchain yang tersedia kepada pemilih tanpa melalui proses verifikasi keanggotaan. Itu dikarenakan admin sudah terlebih dahulu membuat list, siapa saja mahasiswa yang masih memiliki hak untuk memilih dan siapa saja yang sudah tidak memiliki hak untuk memilih. Selanjutnya, pemilih dapat mengakses halaman pemilihan dan melakukan aktivasi akun blockchain yang sudah disediakan oleh admin. Setelah akun blockchain di aktifkan pemilih dapat langsung melakukan pemilihan calon ketua. Pada saat pemilih sudah selesai melakukan pemilihan, sistem akan otomatis menampilkan hasil pemilihan. Dengan begitu, baik pemilih maupun admin yang bertugas dapat samasama memantau jalannya pemilihan. Disitulah letak transparansi yang diharapkan, karena transparansi pada pemilihan sangat diperlukan mengingat pemilihan dilakukan untuk mendapatkan ketua umum organisasi dan untuk menunjang organisasi tersebut.

Agar pemilih dapat ikut memantau jalannya pemilihan, dengan me-refresh halaman pemilihan dan melihat sudah sejauh mana pemilihan berlangsung begitupun dengan admin. Pada sistem ini dirancang pula agar setiap pemilih yang telah melakukan pemilihan tidak dapat melakukannya lagi. Karena setiap akun dan private-key yang dibagikan admin kepada pemilih hanya berlaku satu kali pemakaian. Pada pemilihan ini, blockchain digunakan pada akun

R Budi Raharjo, Nur Fitriani F, Shafira Mutiara N 
pemilih dan nomor kandidat dari calon ketua yang terdaftar.

\section{IV.2 Hasil Penelitian}

Setelah membuat pemetaan proses bisnis dan memberikan solusi, proses selanjutnya yaitu memperlihatkan hasil dari rancangan dari sistem $e$ voting berbasis blockchain. Sistem tersebut akan digambarkan menggunakan flowchart dan terlihat seperti pada Gambar 7

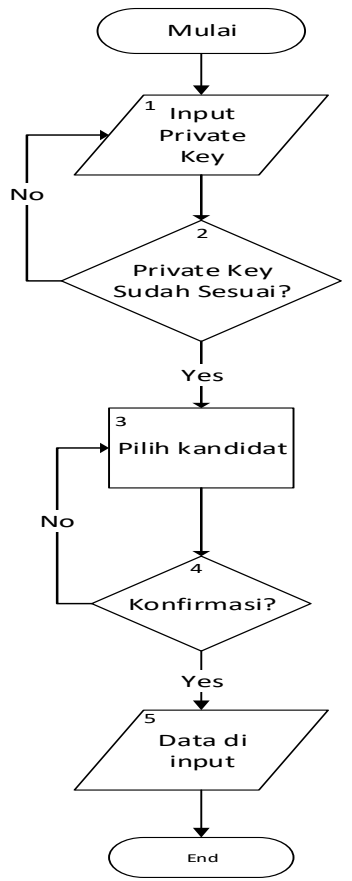

\section{Gambar 7. Flowchart Sistem E-voting Berbasis Blockchain}

Seperti yang terlihat pada Gambar 7 proses dari sistem $e$-voting yang telah dirancang dimulai dari:

1) Menginput private key yang didapatkan dari aplikasi Ganache untuk mengaktifkan akun pemilih dilakukan di plugin Metamask.

2) Jika private-key yang diinputkan sudah tepat atau belum pernah digunakan untuk melakukan voting, maka akun berhasil diaktivasi dan dapat digunakan untuk melakukan voting.

3) Setelah akun diaktivasi, voter melakukan pemilihan dengan memilih kandidat yang dilakukan dengan memilih salah satu kandidat yang muncul pada button drop-down kemudian menekan button 'submit'.
4) Kemudian jika sudah menekan tombol 'submit' plugin Metamask akan meminta konfirmasi dari voter untuk melakukan transaksi pemilihan.

5) Pada saat konfirmasi sudah dilakukan oleh voter, transaksi pemilihan diinput di aplikasi Ganache. Ganache membuat blok baru yang berisi transaksi pemilihan, kemudian blok tersebut dihubungkan dengan blok sebelumnya menggunakan nilai hash.

Metamask merupakan plugin yang terinstal pada browser yang digunakan untuk melakukan pemilihan, Metamask digunakan untuk mengkoneksikan sistem $e$ voting yang dibuat dengan aplikasi Ganache.

Sementara Ganache adalah aplikasi penyedia akun blockchain yang digunakan untuk melakukan pemilihan. Pada aplikasi ini pula seluruh pencatatan terhadap aktifitas akun blockchain dilakukan termasuk pembuatan nilai hash. Selanjutnya, untuk proses prototyping hingga implementasi dan pengujian pada sistem yang diusulkan, dapat dilihat pada jurnal penelitian selanjutnya.

\section{KESIMPULAN DAN SARAN}

Berdasarkan analisa, pemetaan proses dan perancangan sistem yang dilakukan, dapat ditarik kesimpulan bahwa:

1) Analisa, pemetaan proses dan perbaikan proses pemilihan ketua umum organisasi berhasil dilakukan.

2) Ditemukan solusi dari permasalahan yang ada dengan diusulkannya pembangunan sistem $e$ voting berbasis teknologi blockchain.

3) Rancangan dari pembangunan sistem telah dibuat dan disetujui

4) Berdasarkan pemetaan proses yang telah dilakukan dan perancangan sistem yang telah dibuat bahwa penggunaan aplikasi $e$-voting berbasis teknologi blockchain ini dapat memangkas biaya cukup besar untuk pelaksanaan pemilihan.

\section{REFERENCES}

(BPPT) Badan Pengkajian dan Penerapan Teknologi. (2017). E-Voting Untuk Pemilu 2014

Aaiim. (2019). What is Business Process Management? 
Brocke, J. V. (2010). The Handbook o)n Business Process Management 2010

Hanifatunnisa, R., \& Rahardjo, B. (2017). Perancangan Dan Implementasi Sistem Pencatatan EVoting Berbasis Blockchain

IPQI. (2018). Bisnis Proses (Business Process Management)

Jeston, J., \& Neils, J. (2014). Business Process Management

Maryasa. (2018). PERANCANGAN APLIKASI EVOTING PEMILIHAN KETUA BADAN EKSEKUTIF MAHASISWA (BEM) PADA UNIVERSITAS BHAYANGKARA JAKARTA RAYA

Menaesolution. (2019). Business Process Management (BPM)

Yusriannur, M. (2014). Aplikasi E-Voting Berbasis Web untuk Menunjang Pemilihan Presiden Mahasiswa Pada Universitas Dian Nuswantoro Semarang 